\title{
OBSERVATIONS ON THE ABSORPTION, APPARENT VOLUME OF DISTRIBUTION, AND EXCRETION OF THIOUREA
}

\author{
BY LEON C. CHESLEY
}

(From the Margaret Hague Maternity Hospital, Jersey City)

(Received for publication February 3, 1944)

A study of the manner in which the body handles ingested thiourea is of interest for at least two reasons. It has been suggested that thiourea might be used to measure the total body water, and secondly, thiourea is coming into use as a therapeutic agent in the treatment of hyperthyroidism.

As regards the first consideration, thiourea is structurally very similar to urea. Urea has long been thought to be evenly distributed in all of. body water (1), though very recent work indicates that this may not be the case as between plasma water and red blood cell water (2). Thiourea in doses of $0.1 \mathrm{gram}$ per $\mathrm{kgm}$. of body weight has been given to 3 subjects, and it was found that the apparent volume of distribution was about 67 per cent of the body weight (3). This, of course, is consonant with the known proportion of the weight represented by the total body water, although the coincidence may be fortuitous. These workers were unable to pursue the problem further, because of the gastrointestinal reactions to the doses of thiourea required to raise the serum concentrations to levels suitable for analysis by their method (10 to 15 $\mathrm{mgm}$. per $100 \mathrm{ml}$. of serum). In a paper appearing the day that this report was submitted for publication, it is shown (4) that smaller doses of thiourea, in dogs, have an apparent volume of distribution in excess of the total body water. Recovery of injected thiourea from the urine ranged from 50 to 82 per cent, which suggests that some of the thiourea is either destroyed or stored somewhere in the body.

As for the use of thiourea in the treatment of hyperthyroidism, a study of the excretion rate should be of value in determining the optimal frequency of dosage. Since very little is known as to the mode of action of thiourea in its antithyroid effect, observations on its recovery in the excreta are of some interest.

The present investigation was undertaken in the hope of measuring total body water. Unfortunately thiourea is not suitable for this purpose, since considerable amounts of ingested thiourea cannot be recovered in the urine or stools, and the apparent volume of distribution increases hour by hour, to values in excess of the body weight. Presumably the irrecoverable fraction of thiourea is either metabolized or concentrated somewhere in the body.

\section{MATERIAL AND METHODS}

Attempts were made to measure the thiourea-available water in 6 normal subjects, one subject being used a second time after an interval of about 3 months. Subjects 1,2 , and 3 were laboratory workers, and numbers 3 to 6 were normal postpartum women done on the fifth and sixth days after delivery.

Each subject was given $1000 \mathrm{mgm}$. of thiourea in fruit juice, orally. Bloods and urines were obtained at the intervals noted in Table I. In 3 cases, all stools were analyzed for thiourea for 3 days after the test was begun. In the 3 puerperal women, samples of breast milk and of blood were taken almost simultaneously, 3 hours after the thiourea was given. Case 1 fasted throughout the first determination; in all other instances, the regular meals were allowed during the test. The simultaneous clearances of urea and of thiourea were determined in each of the tests on Case 1.

Thiourea in serum, urine, feces, and milk was determined by a method published elsewhere (5). Briefly, serum proteins were precipitated by the addition to serum of an equal volume of $2 / 3 \mathrm{~N}$ tungstic acid. Urines were diluted with water to obtain thiourea concentrations of 5 to 10 gamma per ml. Milk and stool specimens were cleared by the addition of $1 / 2$ volume of 10 per cent sodium tungstate containing about 4 per cent of serum protein, followed by $1 / 2$ volume of $2 / 3 \mathrm{~N}$ sulfuric acid. Specimens taken before the administration of the thiourea were similarly prepared as blanks. To one volume of the filtrates or diluted urines was added an equal volume of a modified Grote's reagent, diluted 1:20 with $0.05 \mathrm{M}$ phosphate buffer at pH 6.0. Color development was followed to its maximal intensity, using an Evelyn photoelectric colorimeter and a filter allowing maximal transmission at $580 \mathrm{~m} \mu$. Concurrently with each set of determinations, there were run 5 known concentrations of thiourea in plasma. The accuracy of the thiourea measurements is considered to be \pm 1 per cent. 
TABLE I

The apparent volume of distribution of thiourea, as percentage of the body weight, and the recovery of ingested thiourea from urine

\begin{tabular}{|c|c|c|c|c|c|c|c|c|c|c|}
\hline \multicolumn{2}{|c|}{ 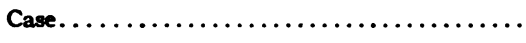 } & $\mathbf{1}$ & $1 \mathbf{a}$ & 2 & 3 & 4 & 5 & 6 & \multirow{3}{*}{ Average } & \multirow{3}{*}{$\begin{array}{c}\text { Average } \\
\text { concentra- } \\
\text { tion of } \\
\text { thiourea } \\
\text { in serum } \\
\text { water }\end{array}$} \\
\hline Sex.......... & 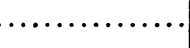 & Male & Male & Male & Female & Female & Female & Female & & \\
\hline Weight, kgm.......... & $\therefore$ & 65.0 & 67.3 & 86.4 & 57.3 & 50.2 & 47.0 & 67.0 & & \\
\hline $\begin{array}{l}\text { Apparent volume of } \\
\text { thiourea distribution, } \\
\text { as percentage of body } \\
\text { weight }\end{array}$ & $\begin{array}{l}1 \text { hour } \\
2 \text { hours } \\
3 \text { hours } \\
4 \text { hours } \\
6 \text { hours } \\
8 \text { hours } \\
10 \text { hours } \\
15 \text { hours } \\
24 \text { hours }\end{array}$ & $\begin{array}{l}74.6 \\
73.2 \\
73.6\end{array}$ & $\begin{array}{c}67.6 \\
76.4 \\
76.9 \\
76.2 \\
85.8 \\
96.6 \\
115\end{array}$ & $\begin{array}{l}75.2 \\
82.1\end{array}$ & $\begin{array}{l}72.4 \\
76.0\end{array}$ & $\begin{array}{r}76.6 \\
86.6\end{array}$ & $\begin{array}{r}75.4 \\
104.8\end{array}$ & 155 & $\begin{array}{l}75.1 \\
85.3\end{array}$ & $\begin{array}{l}1.910 \\
1.875 \\
1.781 \\
1.500 \\
1.260 \\
1.180 \\
0.951 \\
0.684 \\
0.281\end{array}$ \\
\hline $\begin{array}{l}\text { Recovery of thiourea in } \\
\text { urine, mgm. }\end{array}$ & $\begin{array}{l}\text { 1st } 24 \text { hours } \\
\text { 2nd } 24 \text { hours } \\
\text { Percentage } \\
\text { recovered }\end{array}$ & $\begin{array}{r}646 \\
88 \\
73.4\end{array}$ & $\begin{array}{r}672 \\
62 \\
73.4\end{array}$ & $\begin{array}{c}507 \\
88 \\
59.5\end{array}$ & $\begin{array}{r}733 \\
60 \\
79.3\end{array}$ & $\begin{array}{r}706 \\
64 \\
77.0\end{array}$ & $\begin{array}{r}742 \\
69 \\
81.1\end{array}$ & $\begin{array}{r}730 \\
82 \\
81.2\end{array}$ & $\begin{array}{r}677 \\
73 \\
75.0\end{array}$ & \\
\hline
\end{tabular}

Urea in blood and urine were determined by Van Slyke's manometric urease methods (6).

Serum water was determined in each case by weighing $5 \mathrm{ml}$. samples of pooled serum, and drying to constant weight at about $100^{\circ} \mathrm{C}$.

\section{CALCULATIONS}

The thiourea-available water was calculated by dividing the concentration of thiourea in serum water into the apparent residual thiourea. "Residual thiourea" was taken as the difference between the $1000 \mathrm{mgm}$. ingested and the quantity lost in the urine up to the time at which the blood sample was obtained.

\section{RESULTS}

Table I summarizes the attempted measurements of thiourea-available water. In every case, the apparent volume of distribution steadily increases with time, and attains values impossible of representing total body water. This would indicate that some of the thiourea is either metabolized or concentrated somewhere in the body. This deduction is strengthened by the fact that only about three-quarters of the ingested thiourea is recoverable in the urine. Failure of absorption, or reexcretion into the gut, seems to be ruled out by the absence of thiourea in the feces. These results are in accord with those of others, who gave thiourea intravenously to dogs (4).

The recovery of thiourea from the urine was least in the males, and especially in Subject 2 who was almost $20 \mathrm{kgm}$. heavier than any other subject. There are too few cases to decide whether sex and weight really do have a consistent effect upon the quantity (or proportion) of ingested thiourea which disappears. Urinary excretion of the thiourea had practically ceased at the end of 48 hours, the rate during the last 3 hours of this period being only about 1 to $2 \mathrm{mgm}$. per hour. The total excretion in the second 24-hour period was about one-tenth of that in the first 24 hours.

The possibility that some thiourea is destroyed in the gastro-intestinal tract is not excluded by direct evidence. However, the recovery of thiourea from the urine is about the same as was found after intravenous injection in dogs (4).

In the puerperal women, the concentrations of thiourea in breast milk approached very closely the concentrations in the sera taken at the same time as the milk samples.

In one patient who was to have a lumbar puncture, $1000 \mathrm{mgm}$. of thiourea were given by mouth. When the puncture was done 23 hours later (unexpectedly delayed), the serum had been cleared of thiourea, but the spinal fluid showed a concentration of $0.44 \mathrm{mgm}$. per $100 \mathrm{ml}$. This suggests that while the thiourea does gain access to the cerebrospinal fluid, the passage into and out of this system is probably slow.

The renal clearance of thiourea is very close to that of urea, as Table II shows. This is in accord with the work of others (7) on the dog. 
TABLE II

Comparison between the plasma clearances of urea and of thiourea

Calculated on the basis of urea and thiourea concentrations in serum water

\begin{tabular}{|c|c|c|c|c|}
\hline \multirow{2}{*}{ Case } & \multirow{2}{*}{$\begin{array}{c}\text { Urine } \\
\text { volume }\end{array}$} & \multicolumn{2}{|c|}{ Plasma clearance } & \multirow{2}{*}{$\mathrm{C}_{\text {urea/ }} \begin{array}{c}\text { Ratio, } \\
\mathrm{C}_{\text {thiourea }}\end{array}$} \\
\hline & & Urea & Thiourea & \\
\hline $\begin{array}{c}1 \\
\text { fasting }\end{array}$ & $\begin{array}{c}\text { ml. per min. } \\
1.46 \\
1.97 \\
1.41 \\
1.74\end{array}$ & \begin{tabular}{|c|} 
ml. per min. \\
54.2 \\
87.3 \\
66.1 \\
60.2
\end{tabular} & \begin{tabular}{|c} 
ml. per min. \\
55.7 \\
85.6 \\
64.1 \\
60.8
\end{tabular} & $\begin{array}{l}0.97 \\
1.02 \\
1.03 \\
0.99\end{array}$ \\
\hline $\begin{array}{c}1 \mathrm{a} \\
\text { not } \\
\text { fasting }\end{array}$ & $\begin{array}{l}2.13 \\
1.19 \\
1.27 \\
1.38 \\
3.11 \\
1.68\end{array}$ & $\begin{array}{l}59.2 \\
49.7 \\
58.2 \\
59.8 \\
68.8 \\
47.6\end{array}$ & $\begin{array}{l}57.2 \\
50.6 \\
56.9 \\
50.9 \\
56.7 \\
47.4\end{array}$ & $\begin{array}{l}1.03 \\
0.98 \\
1.02 \\
1.17 \\
1.21 \\
1.00\end{array}$ \\
\hline Average & & & & 1.04 \\
\hline
\end{tabular}

The last column in Table I gives the average concentrations of thiourea in serum water at different times after the ingestion of the thiourea. The descending curve for these averages is not so smooth as for individual cases, because the averages at some periods are for only 1 or 2 subjects. In general, the serum concentration has fallen to half its maximum at about the tenth hour.

\section{DISCUSSION}

As for the measurement of total body water, there is not much to be said except that thiourea is not suitable for this purpose, as was found in dogs. The promising results, mentioned at the start of this paper (3), might possibly depend upon the inability of the body to metabolize or store more than a few hundred mgm. of thiourea during the period of the test. Such losses from the several thousand mgm. doses which they used would give only small percentage errors.

As for the disappearance of thiourea in the body, it is reasonable to conjecture that the antithyroid effect of this substance depends upon the retained (unrecovered) fraction. Since the concentration in serum falls rather rapidly, perhaps the use of divided doses during the day would prove more effective in inhibiting thyroid activity than would a single daily dose. One thinks of sulfonamide therapy, in which a primary dose is given to obtain the required blood level, which is then maintained by giving smaller divided doses at suitable intervals.

\section{CONCLUSIONS}

Thiourea is not suitable for measuring total body water.

When thiourea doses of $1000 \mathrm{mgm}$. are given by mouth, about 25 per cent of the ingested thiourea cannot be recovered.

None of the ingested thiourea appears in the feces obtained over a 3-day period afterward.

The concentration of thiourea in breast milk approaches very closely the concentration in serum.

Thiourea enters the cerebrospinal fluid, probably slowly.

The renal clearance of thiourea is very close to that of urea.

\section{BIBLIOGRAPHY}

1. Peters, J. P., and Van Slyke, D. D., Quantitative Clinical Chemistry. Vol. I. Interpretations. Williams and Wilkins Co., Baltimore, 1931, p. 335.

2. Ralls, J. O., Urea is not equally distributed between the water of the blood cells and that of the plasma. J. Biol. Chem., 1943, 151, 529.

3. Lavietes, P. H., Private communication.

4. Danowski, T. S., Use of thiourea as a measure of change in body water. J. Biol. Chem., 1944, 152, 207.

5. Chesley, L. C., A method for the determination of thiourea. J. Biol. Chem., 1944, 152, 571.

6. Peters, J. P., and Van Slyke, D. D., Quantitative Clinical Chemistry. Vol. II. Methods. Williams and Wilkins Co., Baltimore, 1932, pp. 361 and 368.

7. Nicholes, H. J., and Herrin, R. C., The tubular reabsorption of urea, thiourea and derivatives of thiourea in the dog kidney. Am. J. Physiol., 1941, $135,113$. 